\title{
Colomastigids (Amphipoda: Gammaridea: Colomastigidae) from the Veracruz Coral Reef System, SW Gulf of Mexico, with a description of two new species associated with sponges
}

\author{
IGNACIO WINFIELD ${ }^{1}$ and MANUEL ORTIZ ${ }^{2}$ \\ ${ }^{1}$ Laboratorio de Crustáceos, Facultad de Estudios Superiores Iztacala-UNAM. Avenida de los Barrios 1, \\ Los Reyes Iztacala, Tlalnepantla, Estado de México. C.P. 54090. E-mail: ignacioc@ servidor.unam.mx \\ ${ }^{2}$ Centro de Investigaciones Marinas-UH, Calle 16 Número 114, e/1ra y 3ra, Playa, Ciudad de la Haban, Cuba.
}

\begin{abstract}
SUMMARY: Two new species of the genus Colomastix (Amphipoda: Colomastigidae) associated with sponges from the Veracruz Coral Reef System, Mexico, SW Gulf of Mexico, are described. The specimens were collected from the sponges Amphimedon compressa and Desmapsamma anchorata at depths between 3 and $12 \mathrm{~m}$. Colomastix sarae $\mathrm{n}$. sp. and Colomastix escobarae n. sp. are compared to other, very similar species of the genus Colomastix. In addition, we provide ecological and distribution information of sponge-inhabiting Colomastix halichondriae, C. irciniae, and C. tridentata collected from this coral reef system.

Keywords: Peracarida, Colomastix, new species, coral reef, Gulf of Mexico, taxonomy.

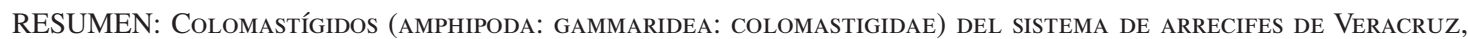

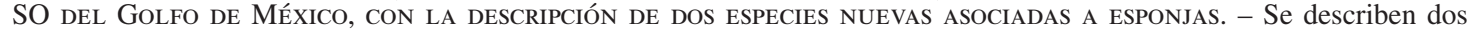
especies nuevas del género Colomastix (Amphipoda: Colomastigidae) asociadas con esponjas del sistema de arrecifes de Veracruz, México, SO del Golfo de México. Los especímenes fueron colectados de las esponjas Amphimedon compressa y Desmapsamma anchorata a una profundidad entre 3 a $12 \mathrm{~m}$. Colomastix sarae $\mathrm{n}$. sp. y Colomastix escobarae $\mathrm{n}$. sp. son comparadas con otras especies cercanas del género Colomastix. Además, se incluye información ecológica y de distribución de Colomastix halichondriae, C. irciniae, y C. tridentata, colectadas de este arrecife de coral y que habitan esponjas.
\end{abstract}

Palabras clave: Peracarida, Colomastix, especies nuevas, arrecife de coral, golfo de México, taxonomía.

\section{INTRODUCTION}

The family Colomastigidae Chevreux, 1899 includes small marine amphipods that inhabit from the intertidal zone to bathyal depths. This pattern of bathymetric distribution shows a decrease in the number of species with the depth and distance from the shore increases, as well as an increase in abundance and biodiversity in the coral reef systems of the continental shelves (LeCroy, 1995). Most colomastigids are symbiotic in sponges and cnidarians, with some records including bryozoans, algae, seagrasses, coral-shell rubble and, less frequently, soft bottoms (Bousfield, 1973; Biernbaum, 1981; Mueller, 1992; Alonso de Pina, 1993).

Colomastigid dispersal and speciation mechanisms are poorly known; however, allopatric speciation by vicariance processes has been documented in coral reefs (LeCroy, 1995; Bousfield, 2000, 2001; Barnard and Karaman, 1991). Therefore, geographical and reproductive isolations occur inside sponges, together with an increase in regional endemism, a wide intra and interspecific morphological variability, and marked sexual dimorphism. In addition, rafting processes and 
TABLE 1. - Geographic locations and depths of sampling stations from the Veracruz Coral Reef System National Park during June, August and October, 2007.

\begin{tabular}{lccc}
\hline Station (Reefs) & Interval depth $(\mathrm{m})$ & Position $(\mathrm{N})$ & Position $(\mathrm{W})$ \\
\hline Blanquilla & $3-10$ & $19^{\circ} 13^{\prime} 32.9^{\prime \prime}$ & $96^{\circ} 05^{\prime} 53.0^{\prime \prime}$ \\
Isla Verde & $4-10$ & $19^{\circ} 12^{\prime} 00.0^{\prime \prime}$ & $96^{\circ} 04^{\prime} 04.4^{\prime \prime}$ \\
Hornos & $5-6$ & $19^{\circ} 11^{\prime} 24.8^{\prime \prime}$ & $96^{\circ} 07^{\prime} 19.8^{\prime \prime}$ \\
Galleguilla & $5-6$ & $19^{\circ} 13^{\prime} 56.5^{\prime \prime}$ & $96^{\circ} 07^{\prime} 31.9^{\prime \prime}$ \\
Blanca & $5-6$ & $1^{\circ} 05^{\prime} 26.4^{\prime \prime}$ & $96^{\circ} 00^{\prime} 01.6^{\prime \prime}$ \\
Isla de Enmedio & $4-12$ & $1^{\circ} 06^{\prime} 00.8^{\prime \prime}$ & $95^{\circ} 56^{\prime} 21.1^{\prime \prime}$ \\
Anegada de Afuera & $8-10$ & $1^{\circ} 10^{\prime} 03.8^{\prime \prime}$ & $95^{\circ} 52^{\prime} 21.4^{\prime \prime}$ \\
\hline
\end{tabular}

transportation by ship biofoulers have been recognized as important mechanisms in the worldwide geographic distribution pattern (Myers, 1993; Ariyama, 2005).

There are less descriptions of new species of colomastigids than those of other families (e.g. Ampeliscidae, Aoridae, Gammaridae, Leucothoidae), due to their small sizes, from millimeters to a few centimeters, the difficulty in identifying the juvenile, pre-mature, mature and post-mature morphs, the difficult conditions for collecting specimens, and the limited sampling area in coral reef ecosystems (LeCroy, 2004).

This study describes two new species of spongeinhabiting colomastigids from the Veracruz Reef System National Park, southwestern Gulf of Mexico, and provides ecological and distribution information on the members of this family currently collected in this reef system.

\section{MATERIALS AND METHODS}

The Veracruz Reef System National Park is located at $19^{\circ} 00.0^{\prime}, 19^{\circ} 16.0^{\prime} \mathrm{N}$ and $95^{\circ} 45.0^{\prime}, 96^{\circ} 12.0^{\prime} \mathrm{W}$, southwestern Gulf of Mexico. In 2007, seven sampling sites (Table 1, Fig. 1) were geopositioned in the bathymetric interval from 3 to $12 \mathrm{~m}$. Sponges were collected manually from each site by scuba divers with a knife, placed in plastic bags underwater and sealed. Once on shore, $5.0 \mathrm{ml}$ of an alcohol/formalin (1:1) solution was added to each sponge to encourage the crustaceans to leave the internal canals. Colomastigids were transferred to glycerin for dissection, illustration, and microstructure analysis under a Motic dissecting microscope at the Crustacean Laboratory, FES-Iztacala, UNAM. Figures were drawn using a camera lucida. The names used for the structures, setae/spines, diagnosis descriptions, and remarks were based on LeCroy $(1995,2004)$.

The type material of the amphipods is deposited in the Colección Nacional de Crustáceos, Instituto de Biología, UNAM, Mexico City. The sponges were deposited and identified in the Colección Nacional del Phylum Porifera Gerardo Green, Instituto de Ciencias del Mar y Limnología, UNAM, Mexico City.

\section{SYSTEMATICS}

Order AMPHIPODA Latreille, 1816 Suborder GAMMARIDEA Latreille, 1802

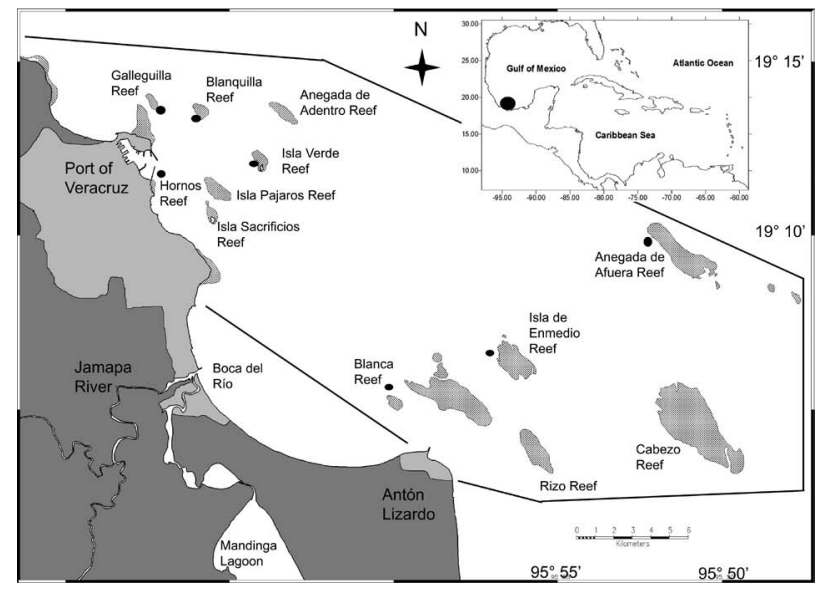

FIG. 1. - Geographic distribution of coral reefs in the Veracruz Coral Reef System National Park, southwestern Gulf of Mexico. The boundaries and the collection localities are included.

\section{Family Colomastigidae Chevreux, 1899 Genus Colomastix Grube, 1861 \\ Colomastix sarae n. $\mathrm{sp}$.}

(Figs. 2-5)

Material examined: Holotype: Adult female (ovigerous), $4.3 \mathrm{~mm}$ (CNCR \#25306); Veracruz Coral Reef System National Park, Blanquilla coral reef, Veracruz, southwestern Gulf of Mexico, coordinates $19^{\circ} 13^{\prime} 32.9^{\prime \prime} \mathrm{N}$ and $96^{\circ} 05^{\prime} 53.0^{\prime \prime} \mathrm{W}, 22$ October 2007, depth 10 $\mathrm{m}$, associated with sponge Amphimedon compressa (Duchassaing and Michelotti, 1864) (Order Haplosclerida; Family Niphatidae) (CNGG \#0897).

Additional material: 2 females (CNCR \#25307); data as for holotype.

Adult male: unknown

Etymology. The new species is named in honor of Sara LeCroy, a researcher of the Gulf Coast Research Laboratory, U.S.A.

Diagnosis: Rostrum acute; interantennal plate, smooth margins projecting further than rostrum, anteroventral angle projecting beyond anterodorsal angle; antenna 1, peduncle article 1 with 3 robust setae on ventral margin, a small distal notch, 3 spines on dorsomedial margin, 2 spines distally; antenna 2, peduncle articles 3-5 with equidistant short robust setae on ventrolateral margin, peduncle article 3 with single distomedial spine and adjacent process, and a robust setae on mediofacial margin; mandible, maxilla 1-2, and outer plate of maxilliped unreduced; maxilliped, basal shell not expanded to form ventral keel; gnathopod 1, simple, elongate; gnathopod 2, insertion of dactylus terminal; peraeopods 3-7, propodus without setae on flexor margin; pleopods 1-3, rami 3-articulate; urosome segment 1 not elongate; uropod 3, outer ramus more robust, ventral margin serrate along two thirds, inner ramus lanceolate and subequal in length to outer, ventral margin not densely setose; telson, ovate, 

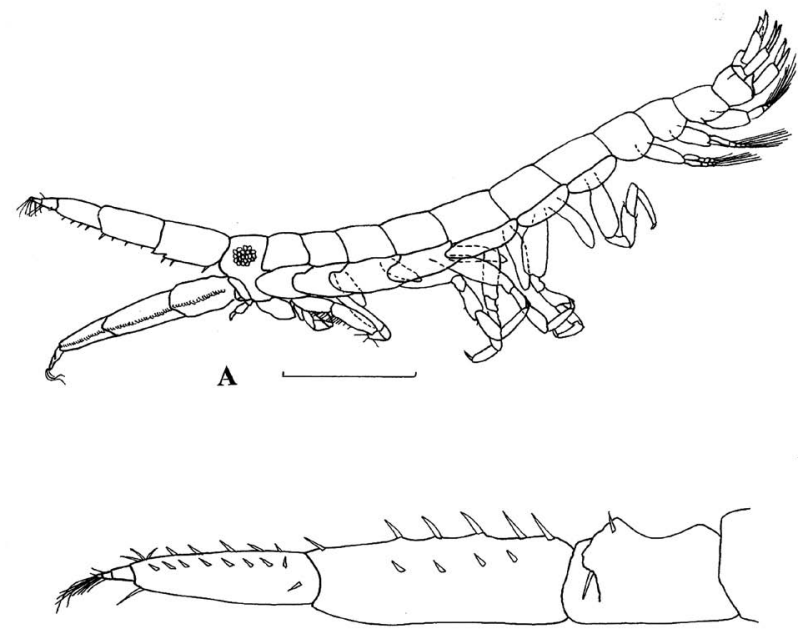

B

C

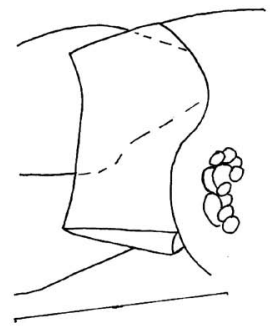

D

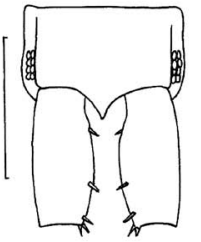

FIG. 2. - Colomastix sarae n. sp., female holotype: A, habitus in lateral view; B, antennae $2 ; \mathrm{C}$, head and interantennal plate in lateral view; $\mathrm{D}$, head in dorsal view. Scale bars: $\mathrm{A}=0.8 \mathrm{~mm} ; \mathrm{B}, \mathrm{C}, \mathrm{D}=$ $0.2 \mathrm{~mm}$.

distal lobule rounded and tongue-shaped, tip rounded, margins not castellated distally.

Description. Holotype, adult female (ovigerous), $4.3 \mathrm{~mm}$.

Body (Fig. 2A). Subcylindrical, long, thin. Antennae subtriangular in cross section, subequal in length. Urosome 1 (Fig. 2A), separate, naked, not elongate; urosome $2+3$ fused, urosome 1 almost 1-1.5 x length of urosome $2+3$ fused.

Antennae (Figs. 2A, B), almost 1/3 body length; antenna 1 (Fig. 2A), peduncle article 1 with 3 robust setae on ventral margin, a small distal notch, 3 spines on dorsomedial margin, 2 spines distally (Fig. 2D); article 2 with 3 small ventral setae, another short robust seta on distal corner; article 3 with 4 small setae on ventral margin; flagellum short, 3-articulate, multisetose, subequal to $1 / 2$ length peduncle article 3. Antenna 2 (Fig. 2A), subtriangular in cross section, peduncle articles 3-5 with short robust setae on ventrolateral margin; article 3 (Fig. 2B) with distomedial process shorter in length than adjacent spine, a robust setae on mediofacial margin; article 4 with 2 lines of 5 and 4 long robust setae each, on dorsal and mediofacial margins, another distal-dorsal; article 5 with a line of 5 robust setae,

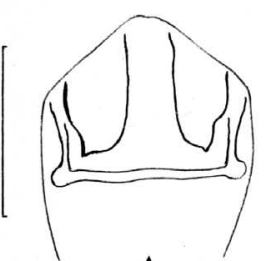

$\mathbf{A}$

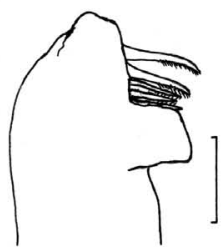

$\mathbf{C}$

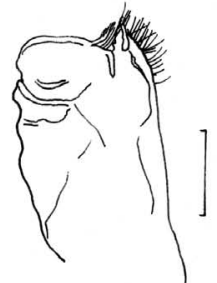

D
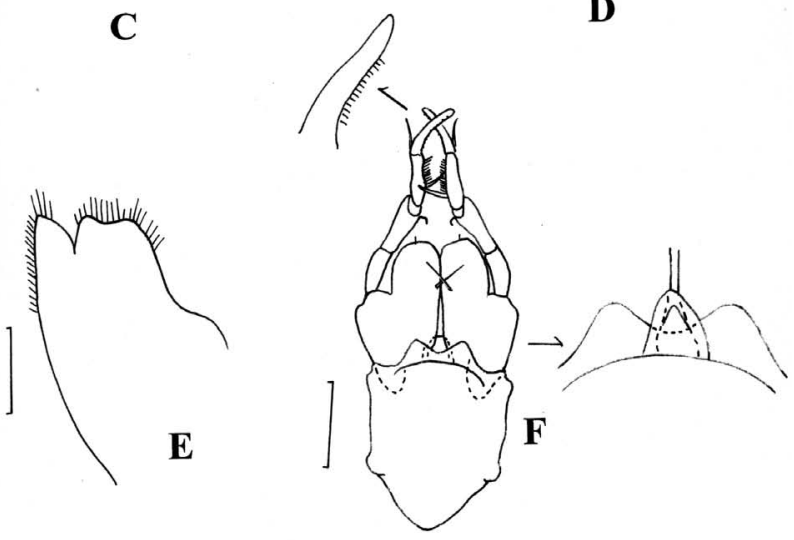

FIG. 3. - Colomastix sarae n. sp., female holotype: A, upper lip; B, lower lip; C, mandible; D, maxilla 1; E, maxilla 2 ; F, maxillipeds. Scale bars: A, B, C, D, E = $0.01 \mathrm{~mm} ; \mathrm{F}=0.1 \mathrm{~mm}$.

and 3 distal setae joined, on dorsal margin, a line of 8 robust setae on mediofacial margin, another ventrofacial, and a long robust seta on ventro-distal angle; flagellum short, 3-articulate, multisetose, subequal to $1 / 2$ length peduncle article 5. Interantennal plate (Fig. 2C), smooth margins, anteroventral angle projecting beyond anterodorsal angle. Rostrum (Fig. 2D), acute, concave margins in dorsal view.

Head (Fig. 2A), width $1.8 \mathrm{x}$ length, subequal to first peraeon segment; eyes compound, 17-18 ommatidia, separation of ommatidia variable.

Coxae (Fig. 2A). Coxae 1-4 subequal in depth and length, anteromedial margin projecting in a convex form, coxa 5 with anteromedial margin projecting in a subtriangular form, coxae 6-7 subequal in length and depth.

Mounthpart bundle (Figs. 3A, B, C, D, E, F). Upper lip subovate (Fig. 3A); lower lip bilobate (Fig. 3B), subquadrate, margins naked, mandible processes reduced; mandible reduced (Fig. 3C), molar subquadrate, surface smooth-nontriturative, incisive rounded, not evident, 5 rakers, curved slightly at distal end, all fused at base; maxilla 1 (Fig. 3D), lobes fused into a subquadrate piece, setae on inner distal corner; $\max$ - 


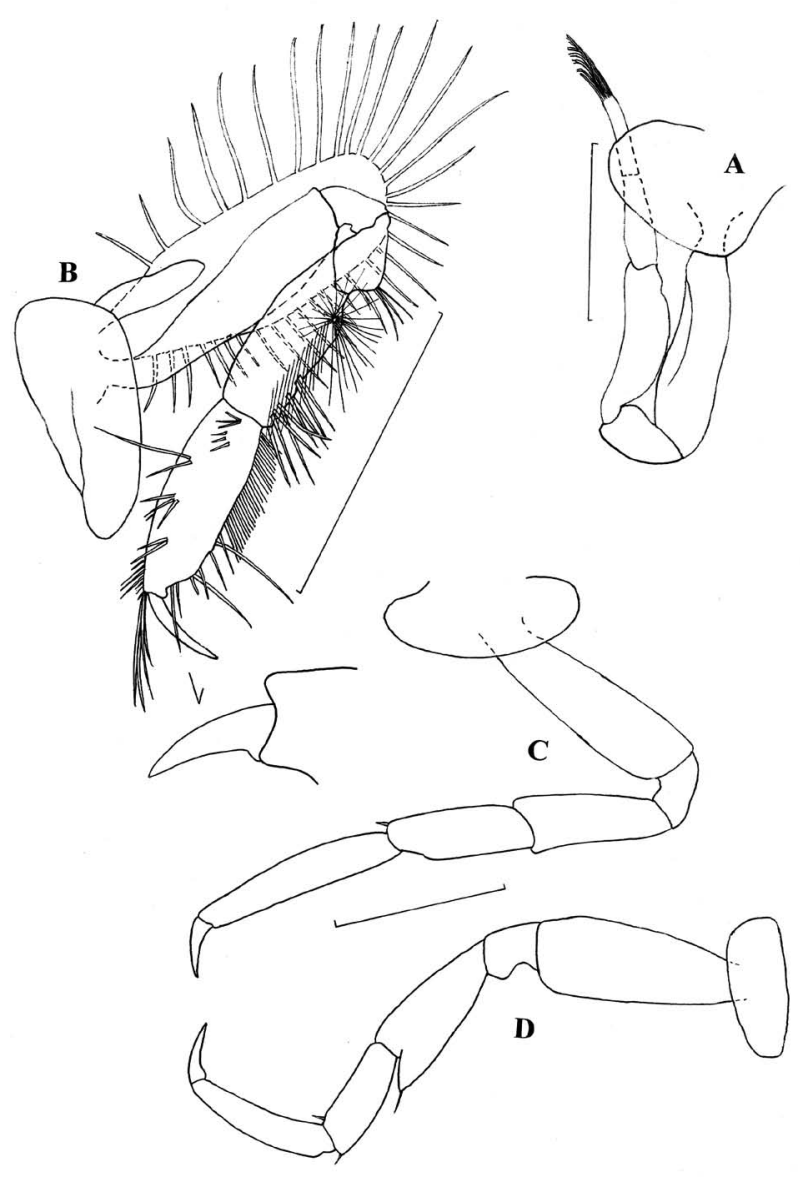

FIG. 4. - Colomastix sarae n. sp., female holotype: A, gnathopod 1; $\mathrm{B}$, gnathopod 2; $\mathrm{C}$, peraeopod 3 (insertion of dactylus is included); D, peraeopod 7. Scale bars: A, B, C, D = $0.2 \mathrm{~mm}$.

illa 2 (Fig. 3E), lobes partly fused, distal margins with equidistant setae, continuous; maxillipeds (Figs. 3F, $5 \mathrm{~A}$ ), outer plates reduced, rounded slightly on proximal margin, a short distal seta on each, on proximal margin, with short distal seta on each, and long, internal, submarginal seta, inner plates completely fused, subovate, basal shell convex distally, not expanded to form ventral keel (Fig. 5A), palps thin, long, a robust seta on article $3,10-12$ short marginal setae, $15-16$ very short marginal setae on article 4, a long proximal seta on external margin.

Gnathopod 1 (Fig. 4A), simple, elongate; merus, carpus and propodus differing in length and width; propodus multisetose distally; dactylus minute, immersed in setae. Gnathopod 2 (Fig. 4B) basis elongate, slightly expanded distally, merus with 5-6 long setae on distal margin, carpus with subcircular-proximal tuft of long and very thin setae, 12-13 long medial setae, equidistant, 9 long robust submarginal setae, all on posterior margin; propodus subequal in length to carpus, distally widened, setose on posterior margin, 2 very long and evident setae on 2/3 posterior margin, 13 long and short external setae, 8-9 continuous and distal setae on anterior margin, 4 long setae on distal corner, subequal

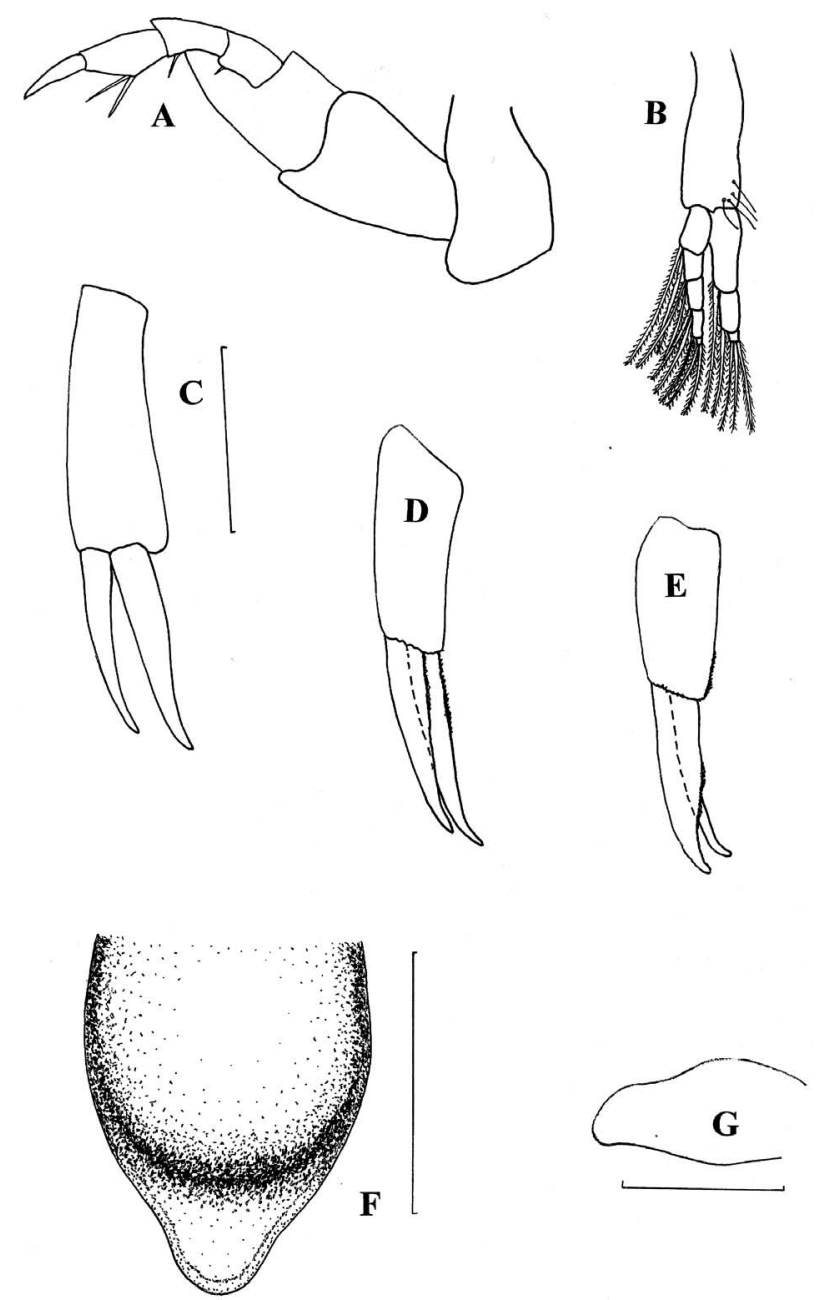

FIG. 5. - Colomastix sarae n. sp., female holotype: A, maxillipeds in lateral view; B, pleopod 1; C, uropod 1; D, uropod 2; E, uropod 3; F-G, telson. Scale bars: C, D, E = $0.2 \mathrm{~mm} ; \mathrm{F}, \mathrm{G}=0.1 \mathrm{~mm}$.

in length to dactylus, insertion of dactylus terminal; oosteguites suboval, long, subequal in basis+ischium length, 35-36 marginal setae.

Peraeopods (Figs. 4C, D) 3-7, propodus without setae on flexor margin. Peraeopods 3-4 similar (Fig. 4C); carpus, a distal robust seta; propodus elongate, $2 \mathrm{x}$ carpus length. Peraeopods 5-7 similar (Fig. 4D); merus with posterior lobe, a distal seta; carpus, 2 setae in both distal corners; propodus curved slightly.

Pleopods (Fig. 5B). Pleopods 1-3 similar; inner ramus 3-articulate.

Uropod 1 (Fig. 5C), peduncle 1.2 x rami length, smooth margins, distoventral corner rounded; inner ramus $1.1 \mathrm{x}$ length of outer, smooth margins on both. Uropod 2 (Fig. 5D), peduncle subequal in length to rami; inner ramus $1.2 \mathrm{x}$ length of outer, anteroventral margins slightly serrate. Uropod 3 (Fig. 5E), peduncle slightly shorter and more robust than rami, distal and distoventral margins serrate slightly; outer ramus more robust, ventral margin serrate along two thirds, inner ramus lanceolate and subequal in length to outer, 
ventral margin not densely setose. Telson (Figs. 5F, G) short, elevated in two first dorsal thirds in lateral view, ovate, distal lobe rounded and tongue-shaped, tip rounded, margins not castellated distally.

Remarks. Colomastix sarae n. sp. may be recognized and differentiated from all other female species of the Colomastix genus by the following characteristics: rostrum acute; head with lineal margins in dorsal view; antenna 1, peduncle article 1 with 3 robust setae on ventral margin, a small distal notch, 3 spines on dorsomedial margin and 2 robust setae distally; antenna 2 , peduncle articles 3-5 with equidistant short robust setae on ventrolateral margin, peduncle article 3 with single distomedial spine and adjacent process, and a robust setae on mediofacial margin; gnathopod 2 without palmar processes; uropod 3, peduncle with distal and distoventral margins serrate slightly, outer ramus more robust, ventral margin serrate along two thirds, inner ramus lanceolate and subequal in length to outer ramus; telson, ovate, distal lobe rounded and tongueshaped, tip rounded.

A morphological comparison of the Colomastix species (female) from the Gulf of Mexico showed that Colomastix sarae n. sp. and C. irciniae are closely related due to the following characteristics: rostrum acute, head with concave slightly margins in dorsal view (lineal in C. sarae); interantennal plate, anterodorsal and anteroventral angles projecting forward subequally (anteroventral angle projecting beyond anterodorsal angle in C. sarae); antenna 1, peduncle article 1 with 2-3 spines on dorsomedial margin ( 3 spines on dorsomedial margin and 2 spines on distal angle in C. sarae); antenna 2, peduncle article 3 with distomedial process shorter than adjacent spine, no robust setae on mediofacial margin (a robust setae in $C$. sarae); oostegite 2 subovate, slightly shorter than basis of gnathopod 2 (longer than basis of gnathopod 2 in $C$. sarae); pleopods 1-3, inner ramus 4-articulate (3-articulate in C. sarae); uropod 3, outer ramus slightly shorter than inner, inner ramus expanded proximally (both subequal in length, inner ramus lanceolate in C. sarae); telson subtriangular, lateral margins minutely pectinate distally, tip smoothly rounded (ovate, distal lobe rounded and tongue-shaped, tip rounded in C. sarae).

\section{Colomastix escobarae n. sp.} (Figs. 6-9)

Material examined: Holotype: Adult female (ovigerous), $5.0 \mathrm{~mm}$ (CNCR \#25381); Veracruz Coral Reef System National Park, Galleguilla coral reef, Veracruz, southwestern Gulf of Mexico, coordinates $19^{\circ} 13^{\prime} 56.5^{\prime} \mathrm{N}$ and $96^{\circ} 07^{\prime} 31.9^{\prime \prime} \mathrm{W}, 07$ August 2007, depth 8 m, associated with sponge Desmapsamma anchorata (Carter, 1882) (Order Poecilosclerida, Family Desmacididae) (CNPGG \#0901).

Adult male, unknown.

Etymology: The new species is named in honor of Elva Escobar Briones, a researcher of the Instituto de Ciencias del Mar y Limnología, México.

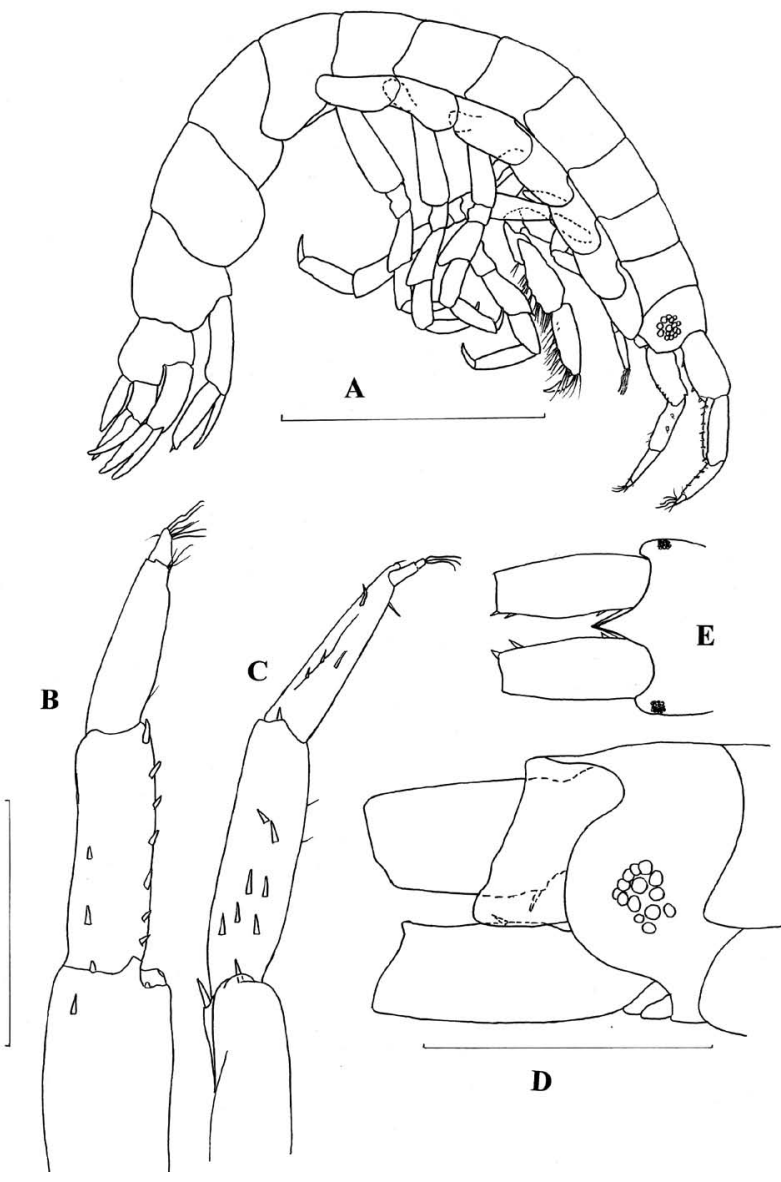

FIG. 6. - Colomastix escobarae n. sp., female holotype. A, habitus in lateral view; B, antennae 1 ; C, antennae $2 ; \mathrm{D}$, head and interantennal plate in lateral view; $\mathrm{E}$, head in dorsal view. Scale bars: $\mathrm{A}=$ $1.5 \mathrm{~mm} ; \mathrm{B}, \mathrm{C}, \mathrm{D}=0.6 \mathrm{~mm}$.

Diagnosis. Rostrum strongly acute; interantennal plate, anteroventral angle projecting further than anterodorsal angle, sinuous slightly anterior margin, projecting further than rostrum; antenna 1 , peduncle article 1with 2 robust setae, another short distal seta on ventral margin, in facial view a robust tooth on distoventral margin, 2 dorsomedial spines, another short distally; antenna 2, peduncle article 3, 5-6 short-thin setae on ventral margin, dorsal margin bifurcate medially in facial view, distomedial process absent, a distomedial long robust seta, another short robust seta on distal margin; article 4, 2 medial robust setae in lateral view, 7 mediofacial robust setae, another on distal margin; article 5, 4 mediofacial short robust setae, a subdistal robust seta on ventral margin; mandible, 7 rakers subequal in length, margins serrate, 5 with differentiated cusps; maxilla 1-2 and outer plate of maxilliped unreduced; maxillipeds, basal shell not expanded to form ventral keel; gnathopod 1, simple, elongate; gnathopod 2 , insertion of dactylus terminal; peraeopods 3-7, articles not elongate, propodus without setae on flexor margin; pleopods 1-3, peduncles long-robust, 2 minute setae on distal margin, rami 3-articulate; urosome segment 1 not elongate; uropod 3, outer ramus wider and 

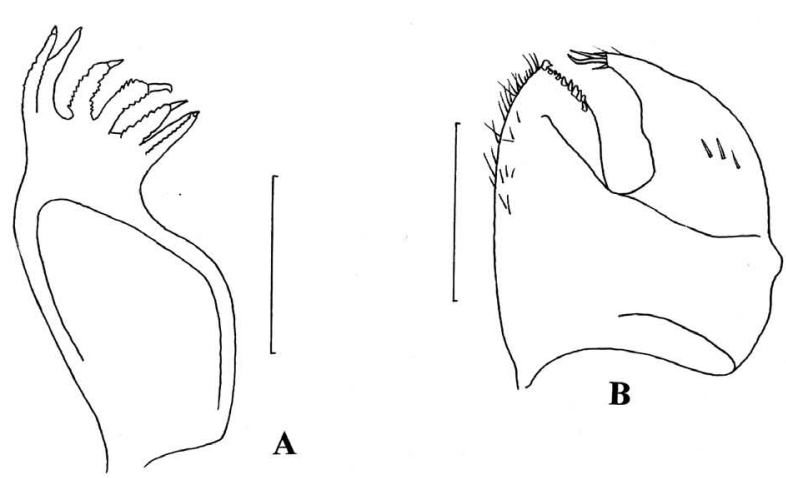

A

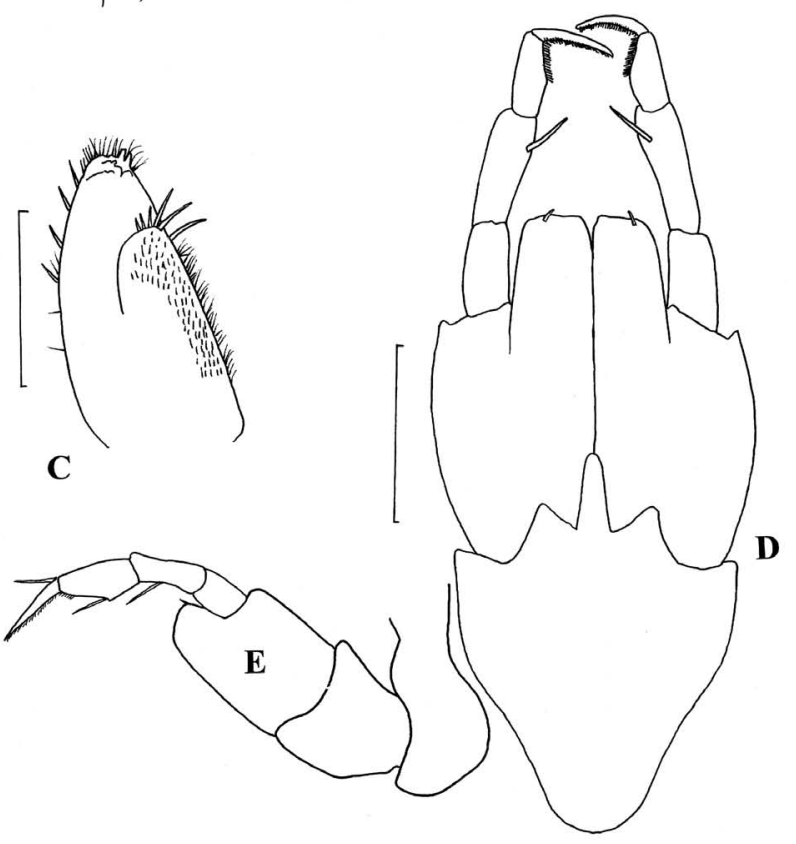

C

FIG. 7. - Colomastix escobarae n. sp., female holotype. A, mandible; B, maxilla 1; C, maxilla 2; D, maxillipeds; E, maxillepds in lateral view. Scale bars: A, B, C, D = $0.4 \mathrm{~mm}$.

longer than outer, serrate, minute setae on ventral margin; inner ramus naked; both tips of rami acute; telson, short, flat in dorsal view, triangular, lateral margins smooth, robust setae absent, tip rounded, margins not castellated distally.

Description. Holotype, adult female (ovigerous), $5.0 \mathrm{~mm}$.

Body (Fig. 6A). Subcylindrical, long, thin, slightly curved. Antennae subtriangular in cross section, subequal in length, almost $1 / 5$ body length. Urosome 1 (Fig. 6A), separate, naked, not elongate; urosome $2+3$ fused, urosome 1 almost 2-2.2 x length of urosome $2+3$ fused.

Antennae (Figs. 6A, B, C); antenna 1 (lateral view), 2 robust setae, another short distal on ventral margin of peduncle article 1, (facial view) a robust tooth on distoventral margin (Fig. 6B), 2 dorsomedial spines, another short distally (Fig. 6E); peduncle article 2, a line of 7 robust setae on ventral margin, 2 mediofa-

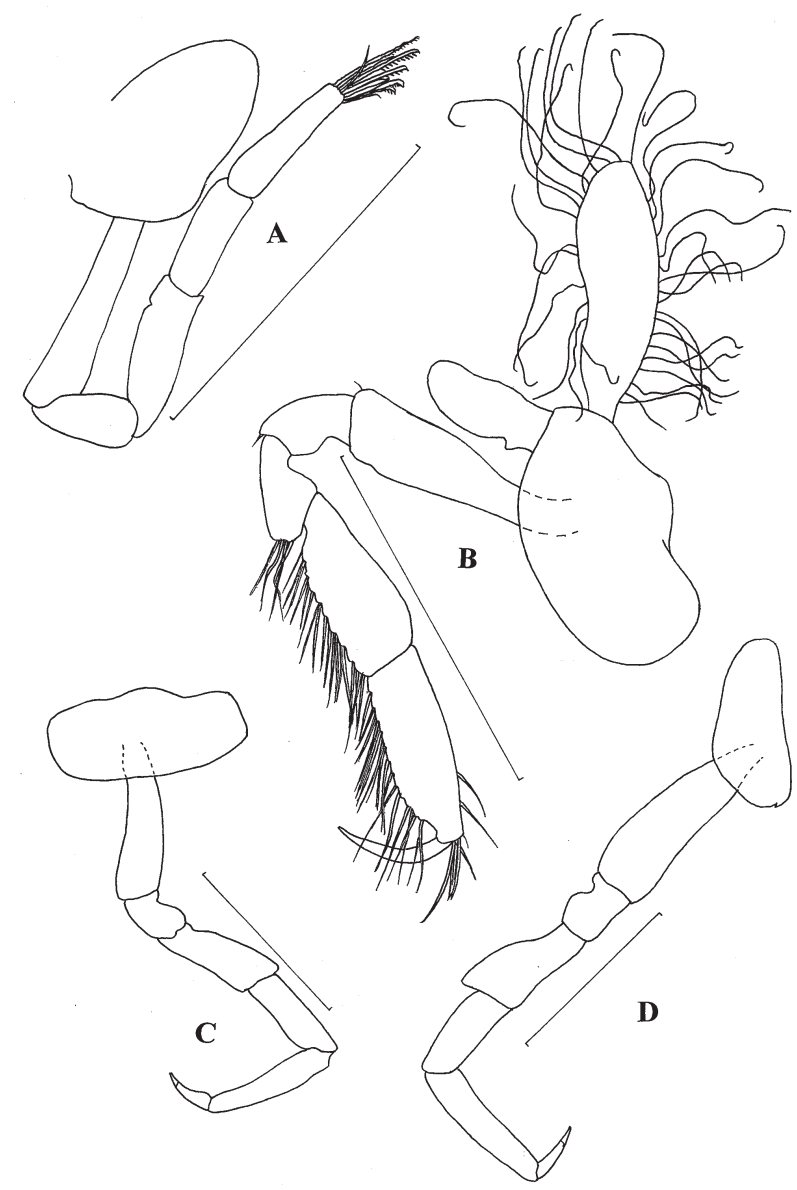

FIG. 8. - Colomastix escobarae n. sp., female holotype. A, gnathopod $1 ; \mathrm{B}$, gnathopod 2 ; C, peraeopod $3 ; \mathrm{D}$, peraeopod 7 . Scale bars: $\mathrm{A}, \mathrm{B}, \mathrm{C}, \mathrm{D}=0.6 \mathrm{~mm}$.

cial; peduncle article 3 (lateral view), 4 robust setae on ventral margin, facial side naked; flagellum short, multisetose, almost 1/4 length article 3. Antenna 2 (lateral view), 5-6 short setae, thin, on ventral margin of peduncle article 3 , (facial view) dorsal margin bifurcate medially (Fig. 6C), distomedial process absent, a distomedial long robust seta (almost 1/7 length peduncle article 3), another short robust seta on distal margin; article 4 (lateral view), 2 medial robust setae, 2 short on ventral margin, (facial view) 7 mediofacial robust setae, another on distal margin, 2 subdistal thin setae on ventral margin; article 5, thin, 4 mediofacial short robust setae, a subdistal robust seta on ventral margin; flagellum short, multisetose, 3-articulate, almost 1/5 length article 5. Interantennal plate (Fig. 6D), anteroventral angle projecting further than anterodorsal angle, sinuous slightly anterior margin, projecting further than rostrum. Rostrum (Fig. 6E), strongly acute, concave margins in dorsal view.

Head (Figs. 6A, D). Subequal in length to first peraeon segment; eyes compound, 14-15 ommatidia, separation of ommatidia variable.

Coxae (Fig. 6A). Coxae 1-4 subequal in depth and length, coxa 1 with anteroventral margin convex; cox- 

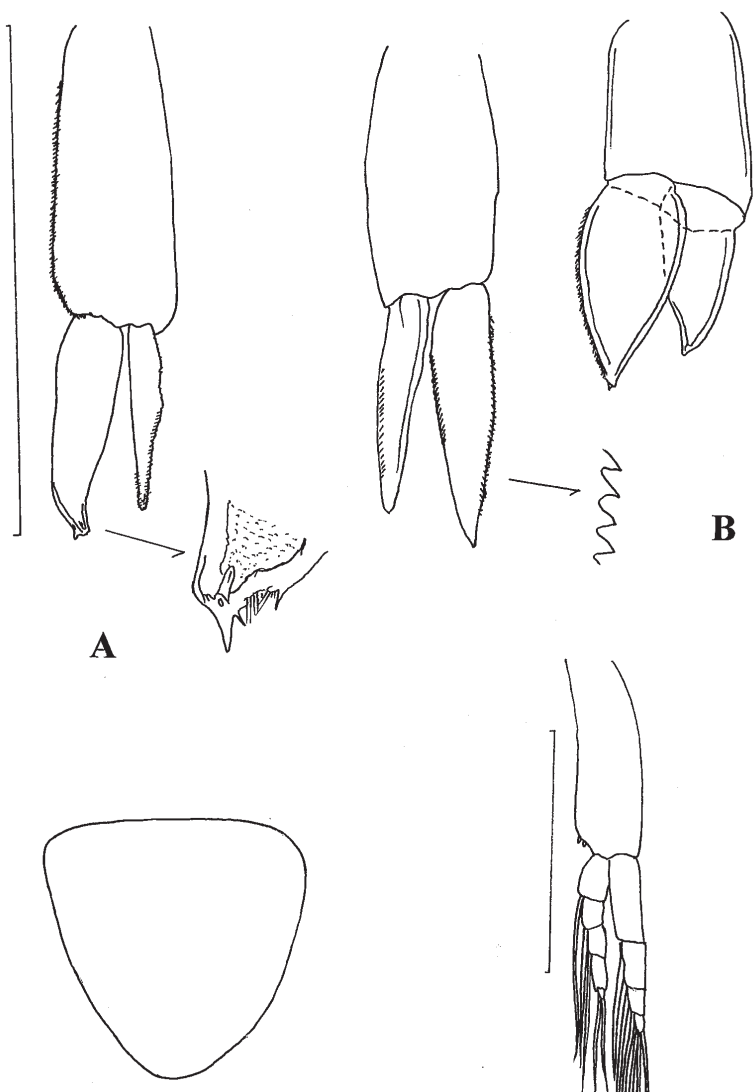

C

$\mathbf{D}$

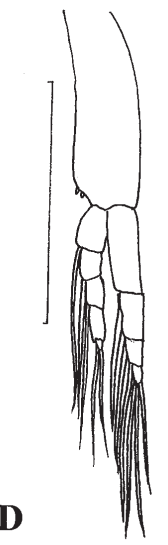

FIG. 9. - Colomastix escobarae n. sp., female holotype. A, uropod 1; B, uropod 2 and uropod 3; C, telson; D, pleopod 1. Scale bars: A, $\mathrm{B}, \mathrm{C}, \mathrm{D}=0.6 \mathrm{~mm}$.

ae 2-5 with anteromedial margin projecting convexly; coxae 6-7, subequal in length and depth.

Mounthpart bundle (Figs. 7A, B, C, D). Mandible reduced considerably (Fig. 7A), molar absent, 7 rakers subequal in length, margins serrate, 5 with differentiated cusps; maxilla 1 (Fig. 7B), lobes separated, internal lobe distally acute, 3 medial thin setae, 3 distal robust setae, 2 distomarginal thin setae, external lobe distally triangular, 9-10 minute robust setae on inner margin, outer margin setose; maxilla 2 (Fig. 7C), lobes partly fused, inner lobe setose on surface and inner margin, outer lobe with distal and external margins setose; maxillipeds (Figs. 7D, E), outer plates reduced, subrectangular shape distally, a short distal seta on each, inner plates completely fused, subtriangular, basal shell rounded distally, no expanded to form ventral keel (Fig. 7E), palps long-thin, $2 / 3 \times$ length of plates, a marginal-subdistal robust seta on article 2 , inner margins setose on articles 3-4.

Gnathopod 1 (Fig. 8A), elongate, simple; merus, carpus and propodus differing in length and width slightly; propodus, 1 tuft of long distal setae, 4-5 pectinate; dactylus minute, immersed in setae. Gnathopod
2 (Fig. 8B), basis expanded distally; merus, 4 distoventral thin-long setae; carpus, 10-11 pair of thin-long setae on ventral margin, crenulate; propodus, elongate, subequal in length to carpus, ventral margin very setose, crenulate, 4-5 distal setae; dactylus, long, thin, almost $1.7 \times$ propodus length, insertion of dactylus terminal; oosteguites developed, subequal in length to basis, margins with very long setae, thin, sinuous.

Peraeopods (Figs. 8C, D) 3-7, articles not elongate, propodus without setae on flex or margin. Peraeopods 3-4 similar (Fig. 8C), propodus thin, $1.2 \mathrm{x}$ length to carpus; dactylus with nail. Peraeopods 5-7 similar (Fig. $8 \mathrm{D})$, merus, a posterior lobe; propodus $1.3 \mathrm{x}$ length to carpus; dactylus with nail. Pleopods 1-3 similar (Fig. 9D), peduncles long, robust, 2 minute setae on distal margin; inner ramus shorter than outer, both 4-articulate, posterior margins setose.

Uropods (Figs. 9A, B). Uropod 1 (Fig. 9A), peduncle longer than rami, almost 1.3 x length, inner margin serrate; inner ramus thicker, slightly longer than outer, 2 distal cusps with minute setae. Uropod 2 (Fig. 9B), peduncle subequal in length to rami, naked; inner ramus thicker and longer than outer, inner margin serrate, second third of the outer margin minutely setose; outer ramus, a line of minute submarginal setae. Uropod 3 (Fig. 9B), peduncle subequal in length to inner ramus; outer ramus wider and longer than inner, serrate, minute setae on ventral margin; inner ramus naked; both tips of rami acute. Telson (Fig. 9C), short, flat in dorsal view, triangular, lateral margins smooth, robust setae absent, tip rounded, margins not castellated distally.

Remarks. Colomastix escobarae n. sp. can be recognized and differentiated from all other female species of the Colomastix genus by the following characteristics: rostrum strongly acute; head with concave margins in dorsal view; interantennal plate with anteroventral angle projecting further than anterodorsal angle, anterior margin projecting further than rostrum, slightly sinuous; antenna 1, peduncle article 1 with a robust tooth on distoventral margin, 2 dorsomedial spines, and another short distally; antenna 2, peduncle article 3 with dorsal margin bifurcate medially, distomedial process absent, a distomedial long robust seta, and another short robust seta on distal margin; mandible with 7 rakers subequal in length, margins serrate, 5 with differentiated cusps; uropod 1 with 2 distal cusps and minute setae on inner ramus; uropod 3, outer ramus wider and longer than inner, serrate, minute setae on ventral margin, inner ramus naked; telson short, flat dorsally, triangular.

A morphological comparison of the Colomastix species (female) from the Gulf of Mexico showed that Colomastix escobarae n. sp. and C. heardi are closely related due to the following characteristics: rostrum acute (strongly acute in C. escobarae), head with slightly concave margins in dorsal view; interantennal plate, anterodorsal and anteroventral angles projecting 
forward subequally (anteroventral angle projecting beyond anterodorsal angle in C. escobarae), anterior margin smooth (slightly sinuous in C. escobarae); antenna 1 , peduncle article 1 with 2 spines on dorsomedial margin (2 dorsomedial spines, another short distally, and a robust tooth on distroventral margin in C. escobarae); antenna 2 , peduncle article 3 , non-dorsal margin bifurcate medially, without process adjacent to distomedial spine (bifurcate medially in C. escobarae); mandible with 5 rakers ( 7 in C. escobarae); oostegite 2 subovate, slightly longer than basis of gnathopod 2 (subequal in C. escobarae); pleopods 1-3, inner ramus 4-articulate; uropod 3, inner ramus shorter than outer, ventral margin densely setose, wedge-shaped (outer ramus with minute setae on ventral margin in C. escobarae); telson subtriangular, tip rounded, margins minutely pectinate (triangular, margins smooth in C. escobarae).

\section{Colomastix halichondriae Bousfield, 1973}

Material examined: An adult female, $6.0 \mathrm{~mm}$ (CNCR \#25850); Veracruz Coral Reef System National Park, Blanquilla coral reef, Veracruz, southwestern Gulf of Mexico, coordinates 19¹3'35.8”N and $96^{\circ} 06^{\prime} 07.7^{\prime \prime} \mathrm{W}$, depth $3 \mathrm{~m}, 22$ October 2007, associated with sponge Amphimedon compressa (Duchassaing and Michelotti, 1864) (Order Haplosclerida, Family Irciniidae) (CNPGG \#0897).

Distribution: Blanquilla coral reef, southwestern Gulf of Mexico. Previous records: from Texas to Cape Sable (west coast of Florida, Gulf of Mexico), Aruba (Caribbean Sea), from Massachusetts to Georgia (east coast of the United States) (LeCroy, 2004).

\section{Colomastix irciniae LeCroy, 1995}

\begin{abstract}
Material examined: An adult male, $5.0 \mathrm{~mm} ; 2$ adult females, $6.0 \mathrm{~mm}$, $5.0 \mathrm{~mm}$ (CNCR \#25851-1); Veracruz Coral Reef System National Park, Blanquilla coral reef, Veracruz, southwestern Gulf of Mexico, coordinates $19^{\circ} 13^{\prime} 35.8^{\prime \prime} \mathrm{N}$ and $96^{\circ} 06^{\prime} 07.7^{\prime \prime} \mathrm{W}$, depth $12 \mathrm{~m}, 23 \mathrm{Oc}-$ tober 2007, associated with sponge Ircinia strobilina (Lamarck, 1816) (Order Dictyoceratyda; Family Irciniidae) (CNPGG \#0883). An adult male, $6.5 \mathrm{~mm}$ (CNCR \#25851-2); Veracruz Coral Reef System National Park, Isla Verde coral reef, Veracruz, southwestern Gulf of Mexico, coordinates $19^{\circ} 12^{\prime} 00.0^{\prime \prime} \mathrm{N}$ and $96^{\circ} 04^{\prime} 04.4^{\prime \prime} \mathrm{W}$, depth 10 m, 22 May 2007, associated with sponge Aplysina fistularis (Pallas, 1766) (Order Verongida; Family Aplysinidae) (CNPGG $\# 0878$ ). Two adult males: $5.0 \mathrm{~mm}, 6.0 \mathrm{~mm} ; 2$ adult females, $5.2 \mathrm{~mm}$, $6.1 \mathrm{~mm}$ (ovigerous) (CNCR \#25851-3); Veracruz Coral Reef System, Isla Verde coral reef, Veracruz, southwestern Gulf of Mexico, coordinates $19^{\circ} 12^{\prime} 00.0^{\prime \prime} \mathrm{N}$ and $96^{\circ} 04^{\prime} 04.4^{\prime \prime} \mathrm{W}$, depth $10 \mathrm{~m}, 22$ May 2007, associated with sponge Ircinia fistularis Verrill, 1907 (Order Dictyoceratyda; Family Irciniidae) (CNPGG \#0913).
\end{abstract}

Distribution. Blanquilla and Isla Verde coral reefs, southwestern Gulf of Mexico. Previous records: west coast of Florida, Florida Keys, and Caribbean Sea (offshore Cabo San Antonio, Cuba, and Pelican Shoals, Belize) (LeCroy, 2004).

\section{Colomastix tridentata LeCroy, 1995}

Material examined: Two adult males: $7.0 \mathrm{~mm}, 6.5 \mathrm{~mm} ; 2$ adult females: $5.5 \mathrm{~mm}, 6.0 \mathrm{~mm} ; 3$ juveniles: $3.0 \mathrm{~mm}, 2.6 \mathrm{~mm}, 2.7 \mathrm{~mm}$ (CNCR \#25852); Veracruz Coral Reef System, Isla Verde coral reef, southwestern Gulf of Mexico, coordinates $19^{\circ} 12^{\prime} 00.0^{\prime} \mathrm{N}$ and $96^{\circ} 04^{\prime} 04.4^{\prime \prime} \mathrm{W}$, depth $10 \mathrm{~m}, 22$ May 2007, associated with sponge Aplysina fistularis (Pallas, 1766) (Order Verongida; Family Aplysinidae) (CNPGG \#0878).

Distribution. Isla Verde coral reef, southwestern Gulf of Mexico. Previous records: Texas, west coast Florida, Florida Keys, Yucatan (Mexico), Caribbean Sea (Gran Cayman Island, Tobago Island, Turks and Caicos Islands, and Georgia and North Carolina (LeCroy, 2004).

\section{DISCUSSION}

LeCroy (1995) published the first extensive study of the family Colomastigidae collected in the northeastern and northwestern Gulf of Mexico, in which she analyzed a variety of taxonomic, biological and ecological topics. This paper included, up to the year 1994, 32 colomastigid species grouped into two genera: Colomastix with 28 species and Yulumara with four. In addition to nine species already described, Ariyama (2005), Ren (2006), and LeCroy (2009) described eight more colomastigid species from Japan, China, and the Great Barrier Reef. By the year 2009, a total of 44 species of Colomastix and five of Yulumara had been recognized. With the descriptions of Colomastix sarae n. sp. and Colomastix escobarae n. sp., the genus Colomastix now has 46 nominal species worldwide (Table 2). Of these, $C$. camura, $C$. tridentata, $C$. cornuticauda, $C$. irciniae, $C$. heardi, $C$. bousfieldi, C. falcirama, C. denticornis, C. gibbosa, C. halichondriae, $C$. janiceae, $C$. sarae n. sp. and $C$. escobarae n. sp. inhabit coral reefs and soft bottoms of the Gulf of Mexico.

Currently, this gulf is the ocean basin with the greatest species richness of the genus Colomastix (13 spp), as $28.3 \%$ of the species found worldwide inhabit this area. It is followed by Madagascar with eight species (equivalent to $17.4 \%$ of the total) (Ledoyer, 1982), the Sea of Japan with seven species (15.2\%) (Bulycheva, 1955; Ariyama, 2005), the Great Barrier Reef with six species (13\%) (LeCroy, 2009), New Zealand (Hurley, 1954), Hawaii (Barnard, 1970), New England (Bousfield, 1973) and the China Sea (Ren, 2006) with two species each (4.3\% respectively), and the Weddell Sea, Antarctic Peninsula, with one species (2.2\%) (Lörz, 2001). This relative difference in the number of colomastigid species could be attributed to several factors: differences in collection effort, the area covered by sampling, the number and structural complexity of the sponges, and the recruitment and dispersion mechanisms in each ocean basin.

Different mechanisms have been documented to explain the dispersion of colomastigid amphipods in the marine environment: Barnard (1976) proposed transportation on rafting materials, that is, attached hosts such as sponges and ascidians; Myers (1993) associated rafting processes with dispersion at a megascale; and Ariyama (2005) considered transportation 
TABle 2. - World list of species in the genus Colomastix (Colomastigidae).

C. armata Ledoyer, 1979

C. azumai Hirayama and Kikuchi, 1980

C. bastidai Alonso de Pina, 1993

C. bousfieldi LeCroy, 1995

C. brazieri Haswell, 1880

C. brevicornis Ledoyer, 1982

C. camura LeCroy, 1995

C. castellata K. H. Barnard, 1932

C. cornuta Ledoyer, 1979

C. cornuticauda LeCroy, 1995

C. denticornis LeCroy, 1995

C. dentipalma LeCroy, 2009

C. fissilingua Schellenberg, 1926

C. escobarae n. sp.

C. falcirama LeCroy, 1995

C. gibbosa LeCroy, 1995

C. halichondriae Bousfield, 1973

C. hamifera Kossman, 1880

C. heardi LeCroy, 1995

C. inaequicornis Ledoyer, 1979

C. irciniae LeCroy, 1995

C. janiceae Heard and Perlmutter, 1977

C. japonica Bulycheva, 1955

C. kapiolani Barnard, 1970

C. keiskama Griffiths, 1974

C. laminosa Lyons and Myers, 1990

C. littoralis Ariyama, 2005

C. longicaudata Ren, 2006

C. lunalilo Barnard, 1970

C. magnirama Hurley, 1954

C. minispinosa Ren, 2006

C. minuta Müller, 1992

C. muravai Myers, 1990

C. plumosa Ledoyer, 1979

C. prionotus Kim and Kim, 1991

C. pusilla Grube, 1861

C. processa LeCroy, 2009

C. sarae n. $\mathrm{sp}$

C. semiplumosa Ariyama, 2005

C. simplicicauda Nicholls, 1938

C. spinosa Ledoyer, 1979

C. subcastellata Hurley, 1954

C. tiahurae Müller, 1992

C. tridentata LeCroy, 1995

C. truncatipes Ledoyer, 1978

C. thomasi LeCroy, 2009

in ship fouling as the main factor in the distributiondispersion process. In this study, two facts suggest that the dispersion and recruitment of colomastigid amphipods in the Veracruz Coral Reef System is mainly associated with the international ships towards the port of Veracruz, both as biofoulers and as organisms in ballast water. Sampling carried out in this coral reef system has confirmed the presence of C. halinchondriae and C. irciniae as macrofoulers on the hulls and in the ballast water, as well as $C$. irciniae and $C$. tridentata as macrofoulers on submerged artificial panels in the northern area of the reef system (Winfield et al. unpublished data).

These changes in the distribution pattern of the Colomastix from the Veracruz Coral Reef System are probably the result of differences in the architectonic complexity, the species richness and relative abundance of sponges, and the impact of maritime traffic, all of which are greater in the northern sector than the southern area. Gómez $(2002,2007)$ documented 46 species of sponges in the Veracruz Coral Reef System, of which 31 species occur in the northern sector; in addition, there is an increase in the complexity of the reef structure in this sector.

Of the nine sponges (Demospongiae) analyzed in this study (Table 3), five included at least one species of Colomastix (55.5\%), with a co-occurrence of $20 \%$ (C. ircinia, C. tridentata versus Aplysina fistularis) (Table 3). This may be an underestimation of the real percentage of occurrence and co-occurrence in this environment, considering the species richness and wide distribution of the recorded sponges, as well as the consistency in the patterns of co-occurrence reported for the genus Colomastix (>30\%) (LeCroy, 1995; Ariyama, 2005).

Host-generalist and host-specific associations have been documented for different species of isopods and amphipods in accordance with the number of host species that they inhabit, and have been explained considering the processes of intraspecific competition and reproductive biology (Thiel, 1999). Based on criteria established by LeCroy (1995), two patterns of distribution-occurrence for the Colomastix and sponge species were observed in this study. The first includes $C$. halichondriae, $C$. tridentata, $C$. sarae n. sp. and C. escobarae n. sp. with a greater degree of host specificity, and the second pattern relates to $C$. irciniae, which showed a generalized distribution in several species of reef sponges (Table 4).

This study provides seven new records of reef sponge species as hosts of the genus Colomastix (Table 4). In addition, we believe that the diversity of the genus Colomastix is poorly known in many regions, including the Gulf of México, and more extensive sampling programs in the Veracruz Coral Reef System itself would probably yield additional species.

TABLE 3. - Occurrence and abundance of Colomastix species among examined sponges at the Veracruz Coral Reef System National Park.

\begin{tabular}{lcccc}
\hline & C. halichondriae & C. irciniae & C. tridentata & C. sarae $\mathrm{n} . \mathrm{sp}$. \\
\hline Aiolochroia crassa & - & - & - & - \\
Amphimedon compressa & 1 & - & - & - \\
Aplysina fistularis & - & 1 & - & - \\
Callyspongia (Cladochalina) almiguera & - & - & - & - \\
Cinachyrella kuekenthali & - & - & - & - \\
Desmapsamma anchorata & - & 4 & - & - \\
Ircinia fistularis & - & 3 & - & - \\
Ircinia strobilina & - & - & - & - \\
Sidonops neptuni & - & - & - \\
\hline
\end{tabular}


TABLE 4. - New records of host sponges for Colomastix species inhabiting the Veracruz Coral Reef System National Park.

\begin{tabular}{lll}
\hline & Previous records & New records (this work) \\
\hline C. halichondriae & $\begin{array}{l}\text { Angelas dispar, Geodia gibberosa, } \\
\text { Halichondria bowerbanki, Haliclona permollis, } \\
\text { Haliclona loosanoffi, Lissodendoryx isodictyalis, } \\
\text { Microciana prolifera, and Spinosella vaginalis } \\
\text { (LeCroy, 2004) }\end{array}$ & Amphimedon compressa \\
C. irciniae & $\begin{array}{l}\text { Ircinia campana and Ircinia felix } \\
\text { (LeCroy, 2004) }\end{array}$ & \\
C. tridentata & $\begin{array}{l}\text { Aiolochroia crassa, Angelas dispar, } \\
\text { Callyspongia fallax, Ircinia spp., Geodia gibberosa, } \\
\text { and Tedania sp. (LeCroy, 2004). }\end{array}$ & $\begin{array}{l}\text { Ircinia strobilina, I. fistularis, } \\
\text { and Aplysina fistularis }\end{array}$ \\
C. sarae n. sp. & None & Aplysina fistularis \\
C. escobarae $\mathrm{n}$. sp. & None & Amphimedon compressa \\
\hline
\end{tabular}

\section{ACKNOWLEDGEMENTS}

We gratefully acknowledge the funds obtained through grants from the CONABIO - project number GN011 (Estudio de las especies invasoras en México) awarded by Comisión Nacional para el Conocimiento y Uso de la Biodiversidad. The authorities of CONAPESCA from the Agriculture and Fisheries Secretaria (SAGARPA), and the administrators of the "Parque Nacional Sistema Arrecifal Veracruzano", in the Port of Veracruz who granted the necessary permits to sample within the Veracruz Reef National Park. We would like to thank in particular Miguel Angel Lozano Aburto (Instituto de Ciencias Marinas y PesqueríasUV) for field assistance, and Patricia Gómez (Instituto de Ciencias del Mar y Limnología, UNAM), who identified the sponges.

\section{REFERENCES}

Alonso de Pina, G.M. - 1993. Two species of Leucothoidea (Amphipoda) from Argentina Sea: Colomastix bastidai new species (Colomastigidae) and Leucothoe spinicarpus (Abildgaard, 1789) (Leucothoidae). Crustaceana, 65(1): 71-81.

Ariyama, H. - 2005. Six species of the genus Colomastix (Crustacea. Amphipoda: Colomastigidae) from western Japan, with descriptions of two new species. Bull. Osaka Mus. Nat. Hist., 59: $1-40$.

Barnard, J.L. - 1970. Sublitoral Gammaridea (Amphipoda) of the Hawaii Islands. Smithson. Contrib. Zool., 34: 1-286.

Barnard, J.L. - 1976. Amphipoda (Crustacea) from the Indo-Pacific tropics: a review. Micronesica, 12: 169-181.

Barnard, J.L. and G.S. Karaman. - 1991. The families and genera of marine Gammaridean Amphipoda (except marine Gammaroids). Parts I. Rec. Aust. Mus., 13(Suppl.): 1-417.

Biernbaum, C.K. - 1981. Seasonal changes in the amphipod fauna of Microciana prolifera (Ellis and Solander) (Porifera: Demospongiae) and associated sponges in a shallow salt-marsh creek. Estuaries, 42(2): 85-96.

Bousfield, E.L. - 1973. Shallow-water gammaridean Amphipoda of New England. Cornell University Press, New York.

Bousfield, E.L. - 2000. Biogeographical analysis of gammaridean amphipod faunas based on their phyletic classification. Pol.
Arch. Hydrobiol., 47(3-4): 335-351.

Bousfield, E.L. - 2001. An updated commentary on phyletic classification of the amphipod Crustacea and its applicability to the North American fauna. Amphipacifica, 3(1): 49-119.

Bulycheva, A.I. - 1955. Novye vidy bokoplavov (Amphipoda, Gammaridea) iz Japonskogo Morja, II. Akademia Nauk SSSR. Tr. Zool. Inst., 21: 193-207.

Gómez, P. - 2002. Esponjas marinas del Golfo de México y el Caribe. AGT Editor, México.

Gómez, P. - 2007. Inventario de las esponjas del Parque Nacional Sistema Arrecifal Veracruzano, con nuevos registros de especies (Porifera: Demospongiae). In: A. Granados, L.G. Abarca and J.M. Vargas (eds.), Investigaciones Científicas en el Sistema Arrecifal Veracruzano, pp. 51-72. Universidad Autónoma de Campeche, México.

Hurley, D.E. - 1954. Studies on the New Zealand amphipodan fauna. No. 6. Family Colomastigidae with description of two new species of Colomastix. Trans. R. Soc. N. Z., 82(2): 419-429.

LeCroy, S. - 1995. Amphipod Crustacea III. Family Colomastigidae. Mem. Hourglass Cruises., 9: 1-139.

LeCroy, S. - 2004. An illustrated identification guide to the nearshore marine and estuarine gammaridean Amphipoda of Florida: Families Bateidae, Biancolinidae, Cheluridae, Colomastigidae, Corophiidae, Cyproideidae and Dexaminidae. U.S.A., Environmental Protection Agency. vol. 3, pp. 411-502.

LeCroy, S. - 2009. Colomastigidae. In: J. K. Lowry and A. A. Myers (eds), Benthic Amphipoda (Crustacea: Peracarida) of the Great Barrier reef, Australia, pp. 348-372. Zootaxa 2260.

Ledoyer, M. - 1982. Crustacés amphipodes gammariens familles de Acanthonotozomatidae á Gammaridae. Faune de Madagascar, 59(1): $1-598$.

Lörz, A.N. - 2001. Low diversity of spongicolous Amphipoda (Crustacea) observed in the Antarctic autumn. Org. Divers. Evol., 1: 133-138.

Mueller, H.G. - 1992. Colomastigidae from coral reef in the Society Islands. Description of two new species (Crustacea, Amphipoda, Gammaridae). Cah. Biol. Mar., 33(4): 425-432.

Myers, A.A. - 1993. Dispersal and endemicity in gammaridean Amphipoda. J. Nat. Hist., 27: 901-908.

Ren, X. - 2006. Fauna Sinica, Invertebrada. Crustacea: Amphipoda: Gammaridea (I), Vol. 41. Science Press, Beijing.

Thiel, M. - 1999. Host-use and population demographic of the ascidian-dwelling amphipod Leucothoe spinicarpa: indication for extended parental care and advanced social bahaviour. $J$. Nat. Hist., 33: 193-206.

Scient. ed.: M. Alcaraz.

Received September 1, 2009. Accepted March 25, 2010.

Published online September 23, 2010. 